Thomas H. Massey, MD, DPhil

Rachel Smith, MD

Shaheena Sadiq, MD

Christopher Overton, MD

Owen R. Pearson, MD

\section{RESCUE OF SEVERE BRAIN AND CERVICAL CORD IRIS BY RESTARTING NATALIZUMAB IN A PREGNANT MS PATIENT \\ OPEN}

Natalizumab inhibits lymphocyte trafficking across the blood-brain barrier, reducing relapse rates by up to $70 \%$ in patients with relapsing-remitting multiple sclerosis (RRMS). Discontinuation of the drug, usually due to pregnancy or risk of progressive multifocal leukoencephalopathy (PML), can trigger the return of disease activity or, occasionally, a fulminant immune reconstitution inflammatory syndrome (IRIS) as lymphocytes re-enter the CNS. ${ }^{1-3}$

We describe a case of life-threatening IRIS following natalizumab cessation in pregnancy, but complete clinical rescue with no adverse sequelae following drug restart in the second trimester.

Case report. A 21-year-old woman was diagnosed with RRMS after 2 disabling relapses within 12 months (1 hemiparetic, 1 dorsal cord, each resolving completely within 4 weeks without corticosteroids) and brain MRI consistent with progressive, active demyelination (figure, A.a-c, worst Expanded Disability Status Scale [EDSS] score 3.0). Monthly IV natalizumab $(300 \mathrm{mg})$ was commenced (negative JC virus [JCV] status) and the patient had no further relapses in the next year (EDSS 1.0). She attended clinic for her 15th infusion and reported that she was 8 weeks pregnant: natalizumab was discontinued. At 16 weeks' gestation (3 months after her last natalizumab infusion), the patient developed rapidly progressive weakness of all 4 limbs over a week. She was hospitalized but deteriorated further, becoming encephalopathic and quadriparetic, with a complex ophthalmoplegia and gross ataxia (EDSS 9.5; bedbound and requiring all care). MRI revealed multiple large new lesions within the cerebral white matter, brainstem, and cerebellum, as well as longitudinally extensive lesions throughout the cervical cord (figure, A.d-h). Contrast was not administered due to pregnancy. Lumbar puncture revealed normal opening pressure and CSF constituents, zero cells, and no microorganisms. Routine blood tests (including anti-aquaporin 4) and urinalysis were normal. Treatment was commenced with acyclovir, IV
Clinical/Scientific Notes

methylprednisolone ( $1 \mathrm{~g} / \mathrm{d}$ for 3 days), and supportive care. Fetal viability was confirmed by ultrasonography.

There was only modest improvement after 2 weeks (EDSS 8.0). PML was ruled out after negative JCV PCR on CSF. Acyclovir was stopped following a negative CSF viral PCR screen. EEG showed diffuse encephalopathic changes but no seizure activity. Following further deterioration, a second course of IV methylprednisolone $(1 \mathrm{~g} / \mathrm{d}$ for 5 days) was administered but there was no improvement, the patient continuing to require 24-hour inpatient nursing care (EDSS 9.5). Given the patient's severe disability, we restarted monthly natalizumab infusions at 24 weeks' gestation, and continued enteral prednisolone. Over the following 2 weeks, the patient's neurologic condition improved dramatically: her encephalopathy lifted, muscle tone and power improved, and balance returned. Further improvements over the next 4 months enabled her to regain independence and return to near baseline (EDSS 4.0; figure, B).

The patient gave birth to a healthy baby girl by elective cesarean section at 40 weeks' gestation (birthweight 3,500 g; Apgar scores of 9 and 10). The infant required phototherapy for mild neonatal jaundice, but was otherwise well: there was no evidence of hematologic disorders. Follow-up MRI postdelivery showed reduced lesion load (figure). One year later, the patient had improved further: her walking was unimpaired, she had mild ataxia only (EDSS 2.0), and her cognitive abilities had recovered to baseline (Addenbrooke Cognitive Examination score 98/100). She could care for her baby, and had re-entered regular employment. Follow-up MRI of brain and cervical cord showed further improvements (figure, A.m-q).

Discussion. This case illustrates a rare life-threatening complication of stopping natalizumab in multiple sclerosis: brain and cervical cord IRIS. Symptom onset coincided with natalizumab washout, and recovery was only seen after restarting treatment during pregnancy. Data on IRIS treatment outside pregnancy suggest that rescue therapy with natalizumab, as here, is most efficacious. Corticosteroids are only moderately beneficial, whereas removing natalizumab by plasma exchange can worsen CNS inflammation. ${ }^{4}$ The recovery observed here was rapid for various reasons: (1) effective blockade of further lymphocyte access to 

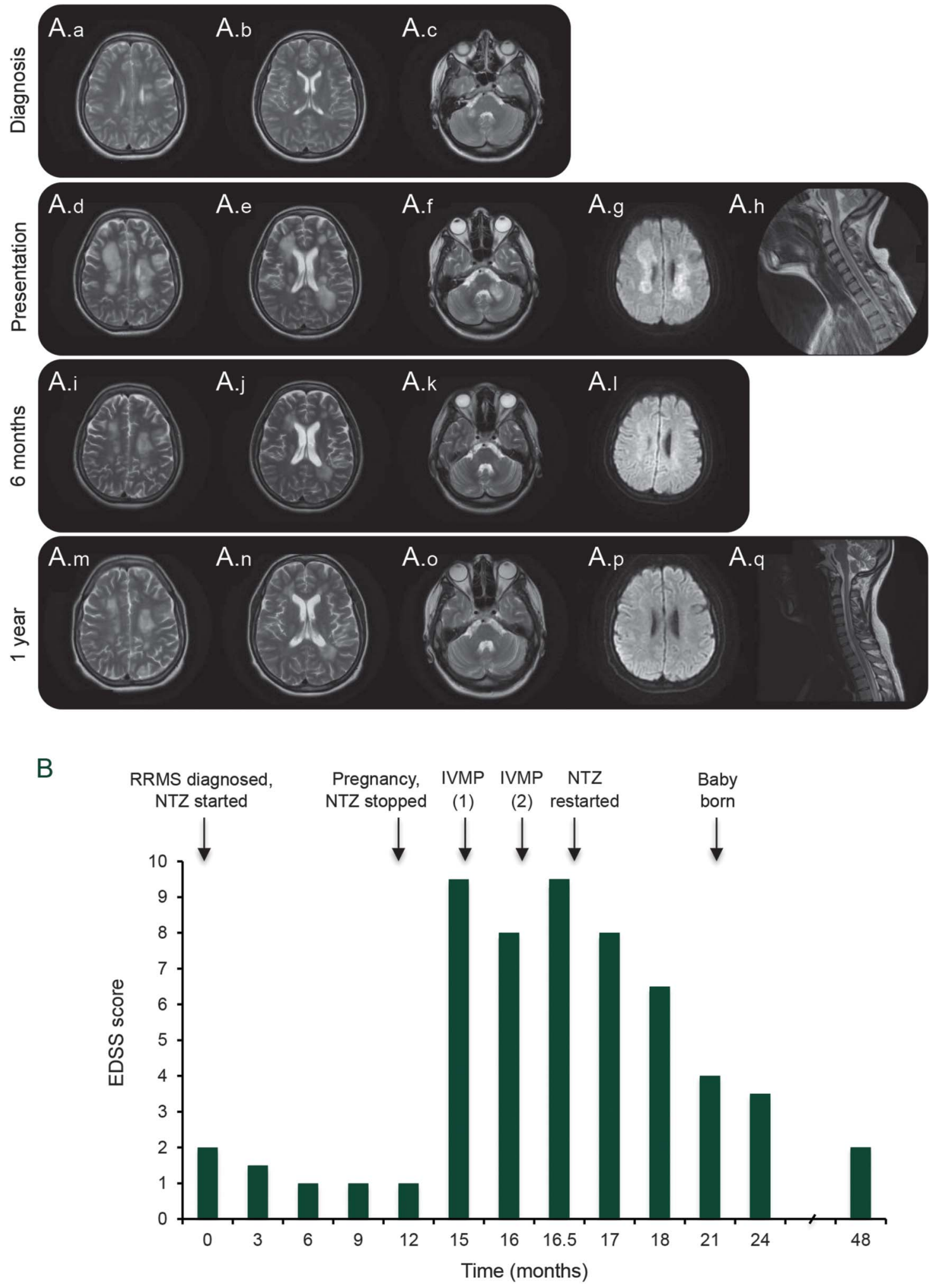

(A) MRI of brain and cervical cord over time. All images are T2-weighted without contrast enhancement except A.g, A.l, and A.p, which are diffusion-weighted (gradient factor $\mathrm{b}=1,000 \mathrm{~s} / \mathrm{mm}^{2}$ ). (A.a-A.c) Brain at diagnosis of multiple sclerosis (pre-natalizumab [NTZ]). (A.d-A.h) Brain and cervical cord at presentation during pregnancy 3 months after cessation of NTZ. (A.i-A.I) Brain 6 months after restarting NTZ. (A.m-A.q) Brain and cervical cord 1 year after restarting NTZ. (B) Bar chart of Expanded Disability Status Scale (EDSS) score against time with major events depicted. IVMP = IV methylprednisolone (course number); RRMS = relapsing-remitting multiple sclerosis. 
the CNS by natalizumab [peak $\alpha 4$-integrin saturation on lymphocytes is achieved 3 days after initial IV infusion and maintained at $>80 \%$ for 4 weeks, sufficient to prevent significant CNS transmigration of lymphocytes ${ }^{5,6}$; (2) ongoing steroid treatment of CNS inflammation; (3) effective endogenous remyelination mechanisms in this patient (suggested by complete and timely recovery from previous disabling relapses); and (4) early resolution of encephalopathy enabling effective therapy and accelerated recovery.

The decision to suspend or continue natalizumab in pregnancy must consider risks to both fetus and mother. Although the risks to the fetus of natalizumab exposure appear low and reversible, ${ }^{7}$ further evidence is required, particularly long-term data on children exposed in utero. Careful counselling at the time of natalizumab initiation in women of childbearing age is imperative.

From ABMU (T.H.M., R.S., S.S., O.R.P.), Morriston Hospital, Swansea; Cardiff University (T.H.M.); and Hywel Dda University Health Board (C.O.), Withybush Hospital, Haverfordwest, UK.

Author contributions: Thomas Massey: study concept and design, data accumulation and interpretation, drafting/revision of manuscript. Rachel Smith: data accumulation and interpretation, revision of manuscript. Shaheena Sadiq: data accumulation and interpretation, revision of manuscript. Christopher Overton: data accumulation and interpretation, revision of manuscript. Owen Pearson: study concept and design, data accumulation and interpretation, drafting/ revision of manuscript.

Acknowledgment: The authors thank the patient and her family for their assistance with this report.

Study funding: No targeted funding reported.

Disclosure: T. Massey has received support to attend a scientific meeting from Novartis. R. Smith, S. Sadiq, and C. Overton report no disclosures relevant to the manuscript. O. Pearson has received honoraria and support to attend scientific meetings, speakers' fees, and advisory boards from Biogen, Genzyme, Novartis, Teva, Merck Serono, and Roche. Go to Neurology.org for full disclosures. The Article Processing Charge was paid by Cardiff University.
This is an open access article distributed under the terms of the Creative Commons Attribution-NonCommercial-NoDerivatives License 4.0 (CC BY-NC-ND), which permits downloading and sharing the work provided it is properly cited. The work cannot be changed in any way or used commercially without permission from the journal.

Received April 28, 2016. Accepted in final form October 27, 2016.

Correspondence to Dr.Pearson: Owen.Pearson@wales.nhs.uk

Copyright ( 2017 The Author(s). Published by Wolters Kluwer Health, Inc. on behalf of the American Academy of Neurology

1. Lenhard T, Biller A, Mueller W, Metz I, Schönberger J, Wildemann B. Immune reconstitution inflammatory syndrome after withdrawal of natalizumab? Neurology 2010; 75:831-833.

2. Tan IL, McArthur JC, Clifford DB, Major EO, Nath A. Immune reconstitution inflammatory syndrome in natalizumab-associated PML. Neurology 2011;77:10611067.

3. Miravalle A, Jensen R, Kinkel RP. Immune reconstitution inflammatory syndrome in patients with multiple sclerosis following cessation of natalizumab therapy. Arch Neurol 2011;68:186-191.

4. Papeix C, Depaz R, Tourbah A, Stankoff B, Lubetzki C. Dramatic worsening following plasma exchange in severe post-natalizumab withdrawal multiple sclerosis relapse. Mult Scler 2011;17:1520-1522.

5. Plavina T, Fox EJ, Lucas N, Muralidharan KK, Mikol D. A randomized trial evaluating various administration routes of natalizumab in multiple sclerosis. J Clin Pharmacol 2016; 56:1254-1262.

6. Rudick RA, Sandrock A. Natalizumab: alpha 4-integrin antagonist selective adhesion molecule inhibitors for MS. Expert Rev Neurother 2004;4:571-580.

7. Ebrahimi N, Herbstritt S, Gold R, Amezcua L, Koren G, Hellwig K. Pregnancy and fetal outcomes following natalizumab exposure in pregnancy: a prospective, controlled observational study. Mult Scler 2015;21: 198-205.
Felix Kleefeld

Sophie Heller

Heiko Jessen, MD

Patrick Ingiliz, MD

Antje Kraft, PhD

Katrin Hahn, MD

\section{EFFECT OF INTERFERON-FREE THERAPY ON COGNITION IN HCV AND HCV/HIV INFECTION: A PILOT STUDY \\ OPEN}

Approval of direct-acting antivirals against the hepatitis $\mathrm{C}$ virus (HCV) has dramatically changed the management of HCV infection due to high cure rates and a favorable safety profile. Their influence on neurologic aspects is notably relevant, as studies demonstrated active $\mathrm{HCV}$ replication within the $\mathrm{CNS}^{1}$ and alterations in cerebral metabolism consistent with neuroinflammatory conditions. ${ }^{2}$ These findings may be causative for cognitive deficits in $\mathrm{HCV}$-infected patients. ${ }^{3}$ Similar impairment has been demonstrated in patients coinfected with HIV, with a prevalence as high as $60 \%{ }^{4}$ Therefore, these patients may particularly benefit from HCV eradication. To date, studies addressing the issue of reversibility of cognitive deficits after HCV therapy are based on interferon treatment, which itself can cause continuing cognitive impairment. ${ }^{5}$ The important question whether these deficits are indeed reversible after $\mathrm{HCV}$ eradication remains unsolved to date.

Methods. We conducted an open observational trial with $\mathrm{HCV}$ and HCV/HIV coinfected patients and planned HCV treatment. Patients with liver cirrhosis (defined as fibroscan $>12.5 \mathrm{kPa}$ ), a history of substance dependence, or cerebral diseases were excluded. HIVinfected patients had to have undetectable plasma HIV levels for at least 6 months. We assessed a comparison group of healthy controls $(\mathrm{n}=30)$ for baseline, but not for follow-up. The neuropsychological test battery 


\section{Neurology}

\section{Rescue of severe brain and cervical cord IRIS by restarting natalizumab in a pregnant MS patient}

Thomas H. Massey, Rachel Smith, Shaheena Sadiq, et al. Neurology 2017;88;711-713 Published Online before print January 11, 2017

DOI 10.1212/WNL.0000000000003604

\section{This information is current as of January 11, 2017}

\section{Updated Information \&} Services

References

Subspecialty Collections

Permissions \& Licensing

Reprints including high resolution figures, can be found at: http://n.neurology.org/content/88/7/711.full

This article cites 7 articles, 2 of which you can access for free at: http://n.neurology.org/content/88/7/711.full\#ref-list-1

This article, along with others on similar topics, appears in the following collection(s):

All Demyelinating disease (CNS)

http://n.neurology.org/cgi/collection/all_demyelinating_disease_cns Multiple sclerosis

http://n.neurology.org/cgi/collection/multiple_sclerosis

Information about reproducing this article in parts (figures,tables) or in its entirety can be found online at:

http://www.neurology.org/about/about_the_journal\#permissions

Information about ordering reprints can be found online:

http://n.neurology.org/subscribers/advertise

Neurology ${ }^{\circledR}$ is the official journal of the American Academy of Neurology. Published continuously since 1951, it is now a weekly with 48 issues per year. Copyright Copyright ( 2017 The Author(s). Published by Wolters Kluwer Health, Inc. on behalf of the American Academy of Neurology. All rights reserved. Print ISSN: 0028-3878. Online ISSN: 1526-632X.

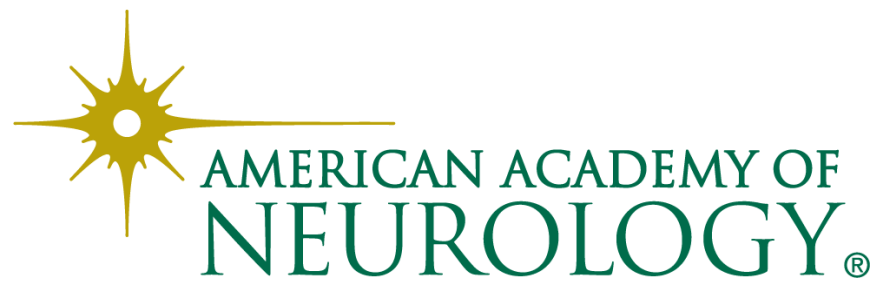

